\title{
Optimalisasi Jaringan Wireless Menggunakan Quality of Serfice (QoS) dan Algoritma Hierarchical Token Bucket (HTB)
}

M.A. Khairul Qalbi (10018145) ${ }^{\mathrm{a}, 1}$, Imam Riadi(0510088001) $)^{\mathrm{b}, 2}$

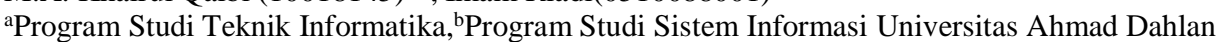

J1. Ringroad Selatan, Kragilan, Tamanan, Kec. Banguntapan, Bantul,,Yogyakarta 55191

1Email : bradaabil@gmail.com; ${ }^{2}$ Email : imam.riadi@is.uad.ac.id;

\section{ABSTRAK}

Masalah kualitas layanan menjadi salah satu aspek penting dari sebuah jaringan computer. Pada jaringan di laboratorium riset UAD ditemukan beberapa masalah antara lain lambat nya kecepatan browsing, tetapi ada juga mahasiswa yang lancar dan cepat sekali ketika melakukan browsing. Pengaturan bandwidth masih menggunakan antrian FIFO. Berdasarkan permasalahan tersebut, perlu dibangun sistem yang dapat memberikan kualitas layanan yang baik, dengan tetap meminimalisir penggunaan bandwidth.

Tahapan dalam penelitian ini terbagi menjadi beberapa langkah yang terdiri dari pengumpulan data, analisis kondisi saat ini, perancangan arsitektur firewall, implementasi, pengujian dan rekomendasi. Tahapan pembangunan sistem terdiri dari perancangan topologi jaringan yang digunakan, konfigurasi awal jaringan yang meliputi konfigurasi interfaces, dhcp server, Ip Forwarding, NAT, DNS dan konfigurasi hotspot, perancangan Quality of Service (QoS) menggunakan metode Hierarchical Token Bucket (HTB). Pengujian sistem dilakukan dengan uji kelayakan pada saat sebelum dan sesudah diterapkannya metode Hierarchical Token Bucket (HTB)

Pengujian yang dilakukan pada sistem ini menggunakan uji kelayakan pada keadaan sebelum dan sesudah diterapkannya sistem. Adapun dari hasil data yang didapat adalah Throughput $128 \mathrm{~Kb} / \mathrm{s}$ kategori bagus, Delay $50 \mathrm{~m} / \mathrm{s}$ kategori sangat bagus, Packet loss $2 \%$ kategori sangat bagus dan Jitter 6,4 sangat bagus. Kesimpulan yang didapat dari hasil pengujian bahwa penerapan Quality of Service (QoS) dan Hierarchical Token Bucket (HTB) mampu memberikan kualitas layanan yang baik dan pemakaian bandwidth sesuai dengan pengaturan yang di tetapkan, sehingga mengurangi pemborosan bandwidth.

Kata Kunci : $Q o S$, HTB, Traffic Control, DHCP.

Ciptaan disebarluaskan di bawah lisensi CC-BY-SA

\section{Pendahuluan}

Masalah kualitas layanan termasuk dalam salah satu aspek penting dari sebuah jaringan internet, seperti pada jaringan komputer. Semakin tinggi pemakaian layanan internet akan semakin tinggi trafik internet yang digunakan, sehingga kecepatan pengiriman data menjadi masalah yang sering dialami dalam jaringan komputer. Instansi pendidikan saat ini menggunakan laboratorium sebagai sarana pendidikannya seperti halnya laboratorium riset UAD. Pada laboratorium riset UAD diterapkan jaringan untuk media praktikum bagi mahasiswa.

Masalah kualitas layanan seringkali menjadi permasalahan utama pada jaringan komputer khususnya pada laboratorium riset UAD. Permasalahan yang ada di antaranya pengaturan bandwidth yang digunakan masih bersifat default dari sistemnya yaitu menggunakan disiplin antrian FIFO.

Berdasarkan masalah tersebut, maka dilakukan suatu penelitian untuk mengoptimalisasi penggunaan Quality of Service dengan metode Hierarchical Token Bucket dan memanajemen penggunaan bandwidth. 


\section{Landasan Teori}

\subsection{Kajian Pustaka}

Berdasarkan hasil penelitian Iskandar \& Hidayat, 2015. Menjelaskan tentang perbandingan nilai parameter Quality of Service waktu jam sibuk dan sepi pada akun mahasiswa dan dosen dengan judul : Analisa Quality of Service $(Q o S)$ jaringan internet kampus (studi kasus : UIN Suska Riau).(Iskandar \& Hidayat, 2015) [1]

Berdasarkan hasil penelitian Wulandari, 2016 Menjelaskan tentang perbandingan nilai parameter Quality of Service menggunakan software Wireshark pada waktu jam kantor dan jam pulang pulang dengan judul : Analisis Quality of Service $(Q o S)$ pada jaringan internet (studi kasus : Upt Loka Uji Teknik Penambangan Jampang Kulon - Lipi). [2]

Berdasarkan hasil penelitian Helmy et al., 2015 Menjelaskan tentang perbandingan penerapan metode simple Queue dan Hierarchical Token Bucket (HTB) dengan menghitung rata - rata trafik upload dan download pada jaringan Makosat Brimob Polda Kalbar dengan judul : Analisis Dan Perbandingan Implementasi Metode Simple Queue Dengan Hierarchical Token Bucket ( Htb ) ( Studi Kasus Makosat Brimob Polda Kalbar ). [3]

Berdasarkan hasil penelitian Lisnawita, 2016 Menjelaskan tentang perbandingan sebelum dan sesudah penerapan metode Hierarchical Token Bucket (HTB) dengan menghitung rata - rata bandwidth yang di dapatkan setiap user dengan judul : Manajemen Bandwidth Menggunakan Metode Hierarchical Token Bucket. [4]

Berdasarkan hasil penelitian Parasian Silitonga, 2014 Menjelaskan tentang penerapan manajemen bandwidth untuk optimalisasi bandwidth pada client dengan menghilangkan IP conflict dengan judul : Analisis Qos ( Quality Of Service) Jaringan Kampus Dengan Menggunakan Microtic Routerboard ( Studi Kasus : Fakultas Ilmu Komputer Unika Santo Thomas S.U). [5]

\subsection{Quality of Service}

QoS (Quality of Service) merupakan Kemampuan suatu jaringan untuk menyediakan layanan yang lebih baik pada trafik data tertentu pada berbagai jenis platform teknologi. [6],[7].

QoS memilliki paramater di antaranya sebagai berikut :

a. Delay

Delay (Latency) merupakan waktu yang dibutuhkan data untuk menempuh jarak dari asal ke tujuan. Delay dapat dipengaruhi oleh jarak, media fisik, congesti atau juga waktu proses yang lama.

b. Jitter

Jitter merupakan variasi delay antar paket yang terjadi pada jaringan IP. Besarnya nilai jitter akan sangat dipengaruhi oleh variasi beban trafik dan besarnya tumbukan antar paket (congestion) yang ada dalam jaringan IP. Semakin besar nilai jitter akan mengakibatkan nilai QoS akan semakin turun. Untuk mendapatkan nilai QoS jaringan yang baik, nilai jitter harus dijaga seminimum mungkin.

c. Throughput

Throughput merupakan jumlah total kedatangan paket yang sukses yang diamati pada destination selama interval waktu tertentu dibagi oleh durasi interval waktu tersebut. Throughput merupakan kemampuan sebenarnya suatu jaringan dalam melakukan pengiriman data. Biasanya throughput selalu dikaitkan dengan bandwidth karena throughput memang bisa disebut juga dengan bandwidth dalam kondisi yang sebenarnya.

Bandwidth lebih bersifat fix sementara throughput sifatnya adalah dinamis tergantung trafik yang sedang terjadi

d. Packet Loss

Packet loss didefinisikan sebagai kegagalan transmisi paket IP mencapai tujuannya. Kegagalan paket tersebut mencapai tujuan. Di dalam implementasi jaringan IP, nilai paket loss ini diharapkan mempunyai nilai yang minimum. 


\subsection{Hierarchical Token Bucket (HTB)}

Hierarchical Token Bucket (HTB) merupakan jenis aplikasi yang dikembangkan oleh Martin Devera pada tahun 2001 yang digunakan untuk membatasi akses menuju ke port/IP tertentu tanpa mengganggu trafik bandwidth pengguna lain. Aplikasi ini berfungsi sebagai pengganti aplikasi yang masih sering digunakan, yaitu. [8],[9]

\subsection{Exence NetTools}

Exence NetTools merupakan software yang digunakan untuk mengukur dan memonitoring kinerja jaringan. Software ini juga dapat menjadi solusi yang baik untuk mendiagnosa permasalahan yang terjadi pada jaringan. Beberapa keunggulan yang dimiliki software diantaranya memberikan hasil riwayat waktu respon data serta packetloss dengan NetWacth secara grafis. [10].

\subsection{Networx Speed Meter}

Networx speed meter merupakan software yang digunakan untuk mengukur nilai throughput. Dengan menggunakan software ini nilai dari parameter throughput dapat di ketahui dengan menjalankan software dan memilih koneksi yang akan dilihat nilai throughputnya pada jaringan yang diakses. [11]

\subsection{Speedtest.net}

Speedtest.net adalah software yang bisa membantu dalam mendapatkan nilai dari parameter delay yang dibutuhkan untuk menghitung nilai dari karakteristik yang diperlukan dalam mencapai quality of service. [12]

\section{Metode Penelitian}

3.1 Metode Observasi

Metode observasi dilakukan dengan melakukan pengamatan secara langsung terhadap jaringan Internet Laboratorium Riset FTI UAD. Hal-hal yang diamati antara lain kecepatan akses Internet pada saat digunakan bersama dan kecepatan akses Internet saat tidak digunakan bersama, baik pada jam sibuk maupun pada saat dipakai untuk praktikum.

3.2 Metode Wawancara

Melakukan wawancara kepada teknisi perangkat IT Universitas Ahmad Dahlan mengenai fasilitas hotspot yang disediakan di Univestas Ahmad Dahlan Kampus 3.

\subsection{Studi Pustaka}

Metode pengumpulan data pada studi pustaka yang dilakukan dengan mencari, membaca dan mengumpulkan dokumen sebagai referensi seperti buku, artikel dan literatur.

\section{Hasil Dan Pembahasan}

\subsection{Perancangan Sistem}

\subsubsection{Perancangan Arsitektur Firewall Paket Filtering}

HTB merupakan salah satu dari teknik management bandwidth yang banyak digunakan, dalam hal ini HTB digunakan oleh penulis untuk memaksimalkan koneksi internet yang tersedia. Berikut rancangan topologi menggunakan $\mathrm{HTB}$, seperti terlihat pada gambar 1



Gambar 1 : Topologi Jaringan menggunakan $H T B$

Skenario yang digunakan adalah dengan menguji sebanyak 5 klien, setiap klien diberikan alokasi bandwidth yang sama. klien-klien yang digunakan bisa dilihat pada tabel 1 
Tabel 1 Pembagian Bandwidth untuk Client

\begin{tabular}{|c|c|c|c|c|}
\hline No & Client & IP Address & $\begin{array}{c}\text { Download } \\
(\mathrm{Kbps})\end{array}$ & $\begin{array}{c}\text { Upload } \\
(\mathrm{Kbps})\end{array}$ \\
\hline 1 & Client 1 & 192.168 .1 .1 & 1024 & 512 \\
\hline 2 & Client 2 & 192.168 .1 .2 & 1024 & 512 \\
\hline 3 & Client 3 & 192.168 .1 .3 & 1024 & 512 \\
\hline 4 & Client 4 & 192.168 .1 .4 & 1024 & 512 \\
\hline 5 & Client 5 & 192.168 .1 .5 & 1024 & 512 \\
\hline
\end{tabular}

\subsection{Implementasi}

\subsubsection{Konfigurasi Htb.init}

Dengan htb.init kita dapat membuat aturan untuk manajemen bandwidth yang disimpan di /etc/sysconfig/htb berbentuk file-file untuk masing - masing aturan yang nantinya akan di compile melalui perintah htb.init compile. Berikut merupakan file konfigurasi HTB download yang sudah dibuat seperti terlihat pada listing 1 :

DEVICE=eth1,10Mbit,1Mbit
RATE=512Kbit
WEIGHT=51.2Kbit
PRIO=1
LEAF=tbf
BUFFER=10Kb/8
LIMIT $=15 \mathrm{~Kb}$
RULE $=192.168 .1 .0 / 24$

Listing 1. Konfigurasi File htb.init Upload

Sedangkan file konfigurasi HTB untuk upload yang sudah dibuat seperti terlihat pada listing 2:

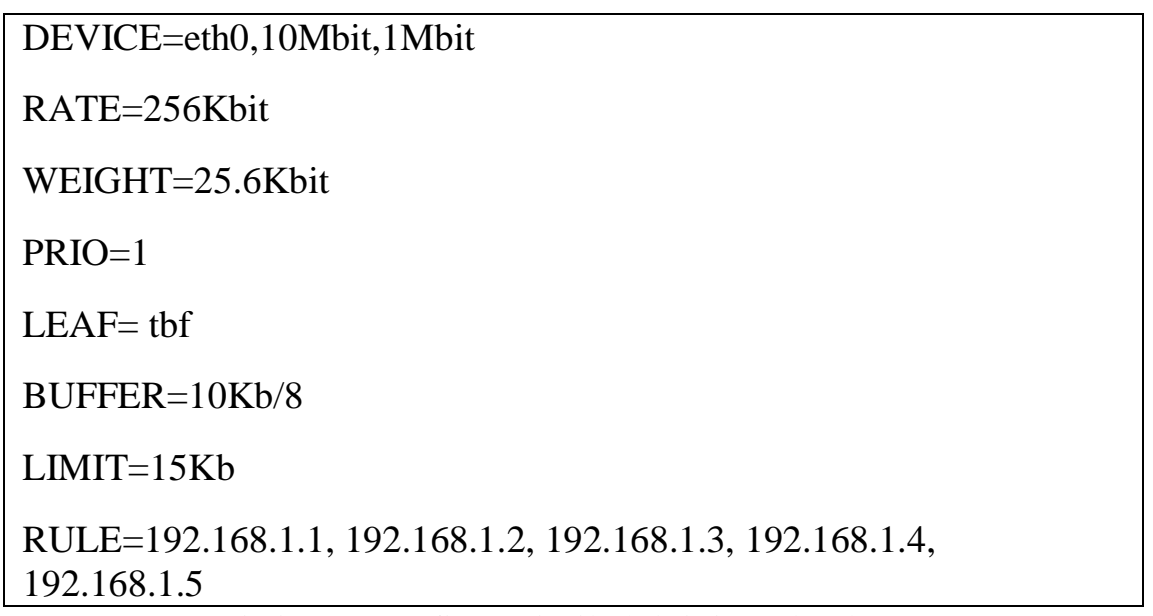

Listing 2 Konfigurasi File htb.init Upload

\subsubsection{Pengukuran Throughput}

Dibawah ini adalah tabel hasil dari pengukuran rata-rata nilai throughput antara pengkuran sebelum dan sesudah, maka untuk mempermudah dalam memahaminya data tersebut dibuat dalam bentuk grafik. Seperti yang terlihat pada gambar 2 . 




Gambar 2 Grafik pengukuran nilai parameter thoroughput.

Terlihat pada gambar 2 merupakan hasil perbadingan antara dua proses perhitungan nilai throughput yang terjadi dalam jaringan yang digunakan untuk melakukan proses pemakaian layanan berupa proses download dan upload pada jaringan Lab Riset.

\subsubsection{Delay}

Dari hasil pengukuran yang telah dilakukan terhadap nilai parameter delay yang telah di hitung maka diperoleh nilai rata-rata perbandingannya antara pengkuran pada tahap sebelum dan sesudah, dari nilai rata-rata yang diambil dapat diketahui nilai delay yang bisa dilihat seperti pada gambar 3



Gambar 3 Grafik perbandingan nilai parameter delay

\subsubsection{Packet Loss}

Nilai dari packetloss yang telah di ukur pada tahapan sebelumnya yang dari kedua nilai yang telah didapat dari dua hasil pengukuran yang telah dilakukan, maka dibawah ini dibuatkan tabel perbandingan diantara kedua nilai tadi, yang di tampilkan nilai rata-rata packetloss yang terjadi dalam bentuk tabel dan dapat dilihat pada gambar 4

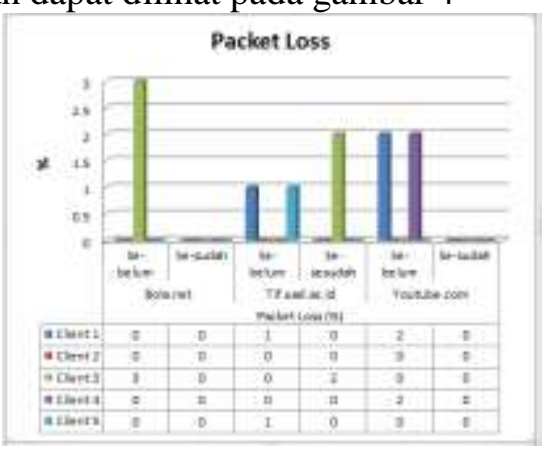

Gambar 4 Grafik perbandingan nilai parameter Packet loss

\subsubsection{Jitter}

Perbandingan nilai parameter jitter didapat dari hasil pengujian yang dilakukan pada tahapan sebelum dan sesudah dengan. Adapun cara dalam mengitung nilai parameter jitter yaitu dengan cara mengaskses jaringan berupa download ataupun upload data atau file pada jaringan tersebut. Berikut ini merupakan gambar perbandingan dari nilai parameter jitter, dapat dilihat pada gambar 5 


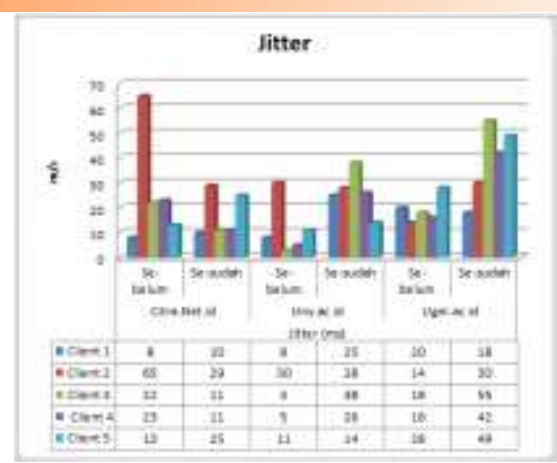

Gambar 5 Grafik perbandingan nilai parameter Jitter

\subsection{Pengujian}

Dalam proses uji kelayakan ini menggunakan standar nilai parameter Quality of Service sebagai acuan dengan melihat hasil dari perhitungan nilai rata-rata pengukuran dari setiap parameter yang kemudian dari nilai tersebut lalu dibandingkan dengan range nilai dari standart yang telah ditentukan terkait dengan penelitian yang dilaksanakan, Seperti yang terlihat pada tabel 2

Tabel 2 perbandingan rata-rata pengukuran

\begin{tabular}{|c|c|c|c|c|c|}
\hline \multirow[t]{2}{*}{ No } & \multicolumn{3}{|c|}{ Quality of Service } & \multicolumn{2}{|c|}{ Hasil } \\
\hline & Parameter & Range & Kategori & Sebelum & Sesudah \\
\hline \multirow[t]{4}{*}{1} & \multirow{4}{*}{ Throughput } & $76 \%-100 \%$ & Sangat Bagus & $1408 \mathrm{~kb} / \mathrm{s}$ & \\
\hline & & $51 \%-75 \%$ & Bagus & & $128 \mathrm{~kb} / \mathrm{s}$ \\
\hline & & $26 \%-50 \%$ & sedang & & \\
\hline & & $<26 \%$ & Jelek & & \\
\hline \multirow[t]{4}{*}{2} & \multirow{4}{*}{ Delay } & $<150$ & Sangat Bagus & $4.4(\mathrm{~m} / \mathrm{s})$ & $50(\mathrm{~m} / \mathrm{s})$ \\
\hline & & $150 \mathrm{sd} .300$ & Bagus & & \\
\hline & & $300 \mathrm{sd} .450$ & sedang & & \\
\hline & & $>450$ & Jelek & & \\
\hline \multirow[t]{4}{*}{3} & \multirow{2}{*}{ Packetloss } & $0 \%$ & Sangat Bagus & $2.6 \%$ & $2 \%$ \\
\hline & & $3 \%$ & Bagus & & \\
\hline & & $15 \%$ & Sedang & & \\
\hline & & $25 \%$ & Jelek & & \\
\hline \multirow[t]{4}{*}{4} & \multirow{4}{*}{ Jitter } & 0 & Sangat Bagus & & \\
\hline & & $1 \mathrm{sd} 75$ & Bagus & 10.8 & 6.4 \\
\hline & & $76 \mathrm{sd} 125$ & Sedang & & \\
\hline & & $126 \mathrm{sd} 225$ & Jelek & & \\
\hline
\end{tabular}

Pengujian yang dilakukan pada sistem ini menggunakan uji kelayakan pada keadaan sebelum dan sesudah diterapkannya sistem. Adapun dari hasil data yang didapat adalah Throughput $128 \mathrm{~Kb} / \mathrm{s}$ kategori bagus, Delay $50 \mathrm{~m} / \mathrm{s}$ kategori sangat bagus, Packet loss $2 \%$ kategori sangat bagus dan Jitter 6,4 sangat bagus.

\section{Kesimpulan}

Jaringan wireless yang dikembangkan menggunakan Qulity of Service dengan metode Hierarchical Token Bucket. Manajemen bandwidth yang dibangun dengan membatasi kecepatan akses untuk mengunduh file pada ekstensi tertentu dan download maupun browsing. Pengujian yang dilakukan pada sistem ini menggunakan uji kelayakan pada keadaan sebelum dan sesudah diterapkannya sistem. Adapun dari hasil data yang didapat adalah Throughput $128 \mathrm{~Kb} / \mathrm{s}$ kategori bagus, Delay $50 \mathrm{~m} / \mathrm{s}$ kategori sangat bagus, Packet loss $2 \%$ kategori sangat bagus dan Jitter 6,4 sangat bagus. Kesimpulan yang didapat dari hasil pengujian bahwa penerapan Quality of Service (QoS) dan Hierarchical Token Bucket (HTB) mampu memberikan kualitas layanan yang baik dan pemakaian bandwidth sesuai dengan pengaturan yang di tetapkan, sehingga mengurangi pemborosan bandwidth. Berdasarkan hasil pengujian dapat 
disimpulkan bahwa penerapan QoS dengan HTB memberikan hasil yang lebih baik dan optimal dalam manajemen bandwidth.

\section{Daftar Pustaka}

[1] Iskandar, I., \& Hidayat, A. 2015. "Analisa Quality of Service ( QoS ) Jaringan Internet Kampus ( Studi Kasus : UIN Suska Riau )". Riau : Jurnal CorelIT, 1(2), 67-76.

[2] Wulandari, R. (2016). "Analisis Qos ( Quality Of Service ) Pada Jaringan Internet ( Studi Kasus : Upt Loka Uji Teknik Penambangan Jampang Kulon - Lipi )”, 2, 162-172.

[3] Helmy, D., Priyanto, H., S, A. S., Studi, P., Informatika, T., \& Tanjungpura, U. (2015). "Analisis Dan Perbandingan Implementasi Metode Simple Queue Dengan Hierarchical Token Bucket ( Htb ) ( Studi Kasus Makosat Brimob Polda Kalbar )”. Sistem Dan Teknologi Informasi, 3.

[4] Studi, P., Informatika, T., Ilmu, F., Universitas, K., Kuning, L., \& Bandwidth, M. (2016). "Manajemen Bandwidth Menggunakan Metode Hierarchical Token Bucket". Teknologi Inormasi \& Komunikasi Digital Zone, x(x), 18-25.

[5] Parasian Silitonga, I. S. M. (2014). "Analisis Qos ( Quality Of Service) Jaringan Kampus Dengan Menggunakan Microtic Routerboard ( Studi Kasus : Fakultas Ilmu Komputer Unika Santo Thomas S.U)". Jurnal TIMES, III(2), 19-24.

[6] Dede fajar riyadi. (2012). Analisa performansi quality of service pada virtual router redundancy protocol menggunakan mikrotik routerboard. Semarang: universitas dian nuswantoro, $1-8$.

[7] A.Supriyono, I.Riadi (2013). Rancang Bangun Sistem Hostpot Menggunakan Captir Portal, Jurnal Sarjana Teknik Informatika.

[8] Wijaya, a. I., handoko, 1. B., kom, m., s, t. I., komputer, f. I., nuswantoro, u. D., ... indonesia, s. (2014). Manajemen bandwidth dengan metode htb ( hierarchical token bucket ) pada sekolah menengah pertama negeri 5 semarang, 5-7.

[9] I.Riadi (2012). Optimasi Bandwidth menggunakan Traffic Shaping, Jurnal Informatika.

[10] Anonym. (2015). Axence NetTools(http://axence.net/en/axence-nettools/)

[11] Anonym.(2015).networx_setup.pdf,(http://getintopc.com/softwares /network/networx2015-free-download/)

[12] Anonym. (2015).Speedtest.pdf, (http://www.speedtest.net/). 